\title{
Analysis of the Influence of Capital Structure, Investment Opportunity Set and Profitability to Value Companies in Manufacturing Companies Before and During Pandemic COVID-19
}

\author{
Merisa Oktaria ${ }^{1,{ }^{*}}$ Rinto Alexandro ${ }^{2}$ \\ 1,2, Economic Education Study Program, Faculty of Teacher Training and Education, Indonesia \\ ${ }^{*}$ Corresponding author. Email: merisa.oktaria@fkip.upr.ac.id
}

\begin{abstract}
This study aims to examine the effect of capital structure, investment opportunity set and profitability on the value of companies in manufacturing companies listed on the Indonesian stock exchange in 2012-2016. This study uses a type of quantitative data using secondary data. Data analysis in this study used multiple linear analysis statistics with the help of the SPSS program. The results of this study indicate that the capital structure does not affect the value of the company, the Investment Opportunity Set has no effect on company value and profitability has an effect on the value of the company.
\end{abstract}

Keywords: Capital Structure, COVID-19, Investment Opportunity Set, Profitability

\section{INTRODUCTION}

The company must have a clear vision and goals. The goals of a company is to get the maximum profit so that the company value, which is reflected in the price of its shares in the capital market, will increase. That matter also will maximize the prosperity of shareholders in the company [1]. The long-term company goals, especially if the company is a publicly traded company, is of course to optimize value of the company. It is because the high value of the company describes the welfare of the company. The value of a company, which already issuing its shares to the public on the capital market, will be reflected in the price company shares. If the company has good prospects, in the future, the stock price will be increasing. Conversely, when the company is considered lacking prospects, the stock price will decline [2]

In early 2020, the Word Health Organization (WHO) established Corona Virus Disease 19 (COVID19) as a pandemic spread throughout the world. This is due to the rapid virus distribution chain has spread to various parts of the world, starting in the City of Wuhan, Hubei Province-China [3][4]. Outside China, COVID-19 has infected 7000 cases and 3000 people have died Indonesia is one of the countries affected the COVID-19 pandemic.

The impacts of COVID-19, which are not only on the health sector but almost on all sectors, are predicted to last a long time [10]. Business sector in Manufacturing Companies is one of the sectors affected by COVID-19. There are manufacturing companies listed on the Indonesia Stock Exchange that use raw materials, parts, and components for producing finished goods. Up to now, many manufacturing companies have faced bankruptcy due to the COVID-19 Pandemic, which affect the unstable economic condition. The aim of this study is to analyze the conditions and influence of the Capital Structure, Investment Opportunity Set and Profitability Against Firm Value in Manufacturing Companies before and during the pandemic (Studies on Manufacturing Companies listed on the Stock Exchange Indonesia in 2015-2019).

The research purposes are:

1) To see the effect of capital structure partially on value manufacturing companies listed on the Indonesia Stock Exchange at 2015-2019.

2) To see the effect of partially determined investment opportunities to the value of companies listed on 
the Indonesia Stock Exchange Indonesia in 20152019.

3) To see the effect of profitability partially on value manufacturing companies listed on the Indonesia Stock Exchange at 2015-2019.

4) To see the capital structure, investment opportunity set and profitability jointly affects firm value manufacturers listed on the Indonesia Stock Exchange in 2012-2016.

5) To see how to analyze the capital structure, Investment Opportunity Set and Profitability on Firm Value in Manufacturing Companies Before and During the Pandemic Period in 2015-2019.

\section{LITERATURE REVIEW}

One of the things that is predicted to affect the value of the company is capital structure because the capital structure will relate to and affect the amount of risk borne by shareholders and the amount of risk that is borne by shareholders [5]. Capital structure is a combination of debt and equity in a long-term financial structure company. Capital structure is usually measured by debt to equity ratio, where DER is the ratio of total long-term debt to total capital. Result research by [6] found that an increase and a decrease in taking longterm debt in the company's capital structure has a unidirectional effect on the value of net income. The increase in debt will affect the size of profits for the company, which reflects the company's capabilities in fulfilling all of its obligations. The results of these studies were also strengthened with the tradeoff theory, which states that if there is an increase in debt it will increase the value of the company. Thus, financial managers need to be careful in determining the capital structure company to optimize company value.

Company value is often associated with the Investment Opportunity Set (IOS), if the company is able to make the right investment decisions then it is an asset the company will produce optimal performance so as to provide a signal positive for investors which will increase share prices and increase in value companies [7]. A company is indicated to develop if the company has a high Investment Opportunity Set (IOS) [8] The development of the company will make investors confident that the company is able to increase the prosperity of the holders shares, so the demand for the company's shares will also increase. An immediate increase in demand for company shares will also give rise for increasing company value.

Besides that, one of the indicators used by investors in choosing stock is to pay attention to its profitability because the higher the profit, the higher the return that investors will get. According to [9], "Profitability is the net results of a number of policies and decision ". Profitability is important in business to maintain the viability of the company in the long run because profitability shows whether the business entity has good prospects in the future.

\section{METHOD}

This research model is based on the influence between the dependent variable company's values (Y) with independent factors such as: capital structure $\left(\mathrm{X}_{1}\right)$, Investment Opportunity Set $\left(\mathrm{X}_{2}\right)$ and Profitability $\left(\mathrm{X}_{3}\right)$.

The data used in this study are publicly traded manufacturing companies listed on the Indonesia Stock Exchange (IDX) from 2015 to 2019. The IDX is designated as a research site because the authors consider the IDX as a place to obtain the necessary data in the form of financial reports and stock prices which is used as the sample in this study. The variables studied are capital structure, investment opportunity set (IOS), profitability and firm value.

This research uses quantitative data, which data is taken from the company's financial statements. Quantitative data is data that is numeric or numeric in nature that can be analyzed using statistics [11] The data in this study comes from secondary data, namely data obtained by reading, studying and understanding through other media which comes from literature, books, and company documents [11].

The population of manufacturing companies that go public listed on the IDX from 2015 to 2019 in this study were 147 companies. The sampling method used was purposive sampling, and the sample in this study only 20 companies were selected.

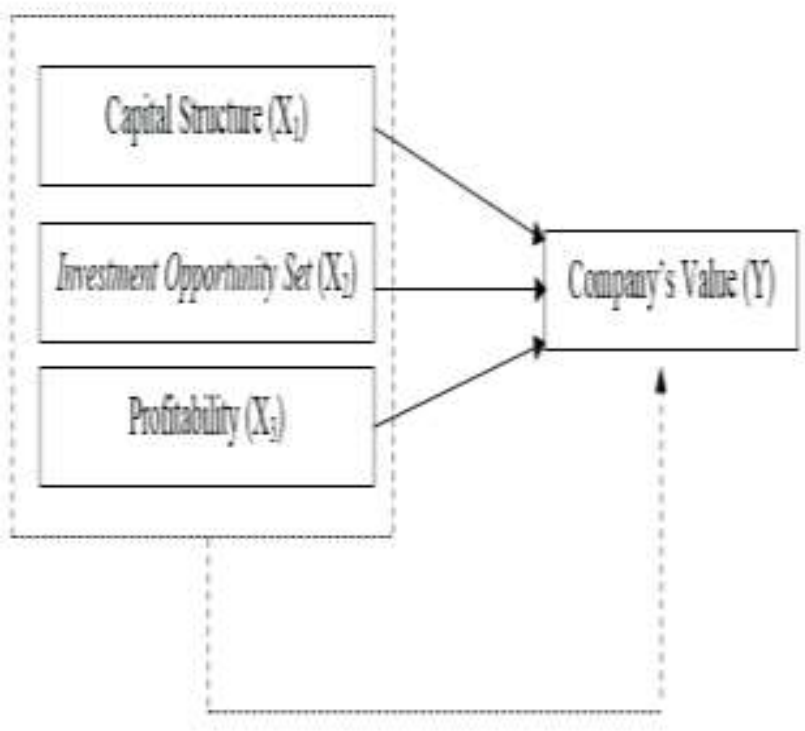

Figure 1. Research Model

Information:

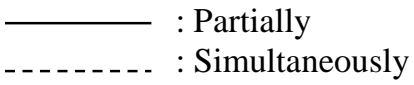


Table 1. Research Sample

\begin{tabular}{|c|l|c|}
\hline No. & \multicolumn{1}{|c|}{ Company names } & Code \\
\hline 1 & PT. Unilever Indonesia, Tbk. & UNVR \\
\hline 2 & PT. Mandom Indonesia, Tbk. & TCID \\
\hline 3 & PT. Merck, Tbk. & MERK \\
\hline 4 & PT. Indofood Sukses Makmur, Tbk. & INDF \\
\hline 5 & PT. Multi Bintang Indonesia, Tbk. & MLBI \\
\hline 6 & PT. Pyridam Farma, Tbk & PYFA \\
\hline 7 & PT. Mustika Ratu, Tbk. & MRAT \\
\hline 8 & PT. Martina Berto, Tbk. & MBTO \\
\hline 9 & PT. Akasha Wira Internasional, Tbk. & ADES \\
\hline 10 & PT. Kedaung Indah Can, Tbk & KICI \\
\hline 11 & PT. Hanjaya Mandala Sampoerna, Tbk. & HMSP \\
\hline 12 & PT. Kalbe Farma, Tbk. & KLBF \\
\hline 13 & PT. Kimia Farma, Tbk. & KAEF \\
\hline 14 & PT. Mayora Indah, Tbk. & MYOR \\
\hline 15 & PT. Nippon Indosari Corpindo, Tbk. & ROTI \\
\hline 16 & PT. Sekar Laut, Tbk. & SKLT \\
\hline 17 & PT. Bentoel Internasional Investama, & RMBA \\
\hline 18 & Tbk. & STTP \\
\hline 19 & PT. Wiantar Top, Tbk & ICBP \\
\hline 20 & PT. Indofood Inti Makmur, Tbk & \\
\hline
\end{tabular}

Data analysis technique is the process of searching for and systematically arranging data that has been obtained from the results of field observations and documentation by organizing data into categories, describing them into units, synthesizing, arranging into patterns, choosing which ones are more important and which will be studied., and draw conclusions so that they are easily understood by oneself and others. Researchers analyzed the data that had been described using multiple linear analysis methods assisted by the SPSS version application. 23. The method used in analyzing the variables in this study is using multiple linear regression.

$$
Y=\alpha+\beta 1 X 1+\beta 2 X 2+\beta 3 X 3+\mathrm{e}
$$

Firm value $(\mathrm{Y})$ is an important measure for investors in investing, because company value is recognized as a good valuation method, and includes the entire company, including in estimating the value of shares in the future and determining the amount of capital in shares. So in this study, researchers used the Market to Book Value ratio as a tool to measure firm value due to the theory described by [12] that: "This Market to Book
Value ratio measures the financial market assessment of company management and organization as going concern". The formula used is:

$$
\text { MBV Ratio }=\frac{\text { Stock Market Price }}{\text { Share Book Value }}
$$

Capital Structure $\left(\mathrm{X}_{1}\right)$, the ratio used to measure the capital structure in this study is the Debt to Equity Ratio (DER). According to [13] states that DER reflects the company's ability to fulfill all of its obligations as shown by how much share of its own capital is used to pay debts. The formula for calculating DER is:

$$
\text { DER }=\frac{\text { Total Payable }}{\text { Total Equity }}
$$

Investment Opportunity Set $\left(\mathrm{X}_{2}\right)$, the ratio used to measure IOS is Capital Additions to Book Assets Value (CAP / BVA) because this ratio is to link the additional flow of company stock capital to productive assets so that it has the potential to be an indicator of a company's growth. Investors can see how much additional capital flows a company has by dividing capital assets by total assets. The greater the flow of additional share capital, the greater the company's ability to use it as additional investment so that the company has the opportunity to grow.

$$
\text { CAP/BVA }=\frac{(\text { Book Value AT }(t)-\text { Book Value AT }(t-1)}{\text { Total Assets }}
$$

Profitability (X3); this profitability measurement refers to the Return on Equity (ROE) which is a ratio used to measure net profit after tax with its own capital. This ratio shows the power to generate a return on investment based on the book value of the shareholders. The higher this ratio, the better, meaning that the position of the company owner is getting stronger, and vice versa. High Return on Equity (ROE) will be able to encourage company acceptance of good investment opportunities and effective cost management. This will affect investors' interest in buying and selling shares, thereby increasing the sales volume of the company's shares. In other words, the level of Return on Equity (ROE) will have an effect on the sales volume of the company's shares. The formula used to calculate Return on Equity (ROE) is as follows):

$$
\mathrm{ROE}=\frac{\text { Net profit after tax }}{\text { Total Equity }}
$$




\section{RESULTS AND DISCUSSION}

In this study, to determine the effect of each variable, namely the capital structure, investment opportunity set and profitability on firm value, multiple linear regression analysis technique can be used. Below are the results of multiple linear analysis that have been tested in this study.

Based on the results of multiple linear regression analysis in Table 2, the regression equation is as follows:

\section{$\mathrm{Y}=11,534+1,274 \mathrm{DER}-1,365 \mathrm{IOS}+23,438 \mathrm{ROE}+3,815 \mathrm{e}$}

The regression equation above can be interpreted as follows:

1) The constant (a) of 11.534 states that if $X 1, X 2$ and $\mathrm{X} 3$ are 0 then the firm value index is 11.534 .

2) The regression coefficient of the DER (Debt to Equity Ratio) variable is 1.274 , which means that an increase of 1 DER (debt to equity ratio) will increase the firm's value by 1.274 . The coefficient is positive, meaning that there is a direct relationship between the capital structure and firm value.

3) The regression coefficient for the IOS (Investment Opportunity Set) variable is -1.365 which means that an increase of 1 unit of IOS (Investment Opportunity Set) will reduce the firm's value by -1.365 . The coefficient is negative, meaning that there is an unidirectional relationship between IOS (Investment Opportunity Set) and firm value.

4) The regression coefficient for the ROE (Return on Equity) variable is 23.438, which means that an increase of 1 unit of ROE (Return on Equity) will increase the firm's value by 23.438 . The coefficient is positive, meaning that there is a direct relationship between profitability and firm value.

Based on the results of the research that has been done, the conclusions of this study are:

1) Capital structure has no effect on firm value, namely by showing a significance value of more than $\alpha=$ $0.05(0.382>0.05)$, meaning that the small amount of debt held by manufacturing companies from 2015 to 2019 in this study is not a reference for investors to glance at these companies, because for investors the most important thing is the company's performance, which is reflected in the company's profits. This shows that if companies increasingly use long-term debt to finance their assets, this is not in line with the increase in firm value in the main sector. This is also inconsistent with the trade-off theory where companies can take advantage of debt while the benefits (tax savings and other costs) are compared with the sacrifice (paying interest). In addition, it is also not in accordance with the Signalling theory which states that when a company uses internal funds to fund its business it will be seen by investors as a significant positive signal because investors perceptions when a company uses debt mean that the company has the ability to increase capacity and pay off debt.

2) The Investment Opportunity Set has no effect on firm value with the statistical significance value of more than $\alpha=0.05 \quad(0.969>0.05)$. The Investment Opportunity Set affects firm value because a high company IOS tends to be considered positive by investors because it has good prospects in the future. However, in this study the Investment Opportunity Set has no effect on firm value, because investors prefer other factors that are easier to observe to assess the company. So IOS in research is not one of the factors that can affect company value, because the company's decision to invest will of course be influenced by an uncertain business climate so that it becomes an uncertain thing for investors.

3) Profitability has an effect on firm value with a significance value less than $\alpha=0.05(0.045<0.05)$. So it can be concluded that ROE is a factor that is able to influence firm value, because the company's performance is able to generate profits for its own company to fund its operations, besides that it can also benefit investors.

Table 2. Result

\begin{tabular}{|c|c|c|c|c|c|c|}
\hline \multirow{2}{*}{\multicolumn{2}{|c|}{ Model }} & \multicolumn{2}{|c|}{ Unstandardized Coefficients } & \multirow{2}{*}{$\begin{array}{c}\text { Standardized } \\
\text { Coefficients } \\
\text { B }\end{array}$} & \multirow[t]{2}{*}{$\mathrm{t}$} & \multirow[t]{2}{*}{ Sig } \\
\hline & & B & Std. Error & & & \\
\hline \multirow{4}{*}{1} & (Constant) & 11,534 & 3,815 & & 3,024 & 0,003 \\
\hline & DER_X1 & 1,274 & 1,452 & 0,094 & 0,877 & 0,382 \\
\hline & IOS_X2 & -1.365 & 34,964 & $-0,004$ & $-0,039$ & 0,969 \\
\hline & ROE_X3 & 23,438 & 11,517 & 0,208 & 2,035 & 0,045 \\
\hline
\end{tabular}


4) Capital structure, Investment Opportunity Set (IOS) and profitability simultaneously have no effect on firm value because $\mathrm{F}_{\text {count }}(1.476)<\mathrm{F}_{\text {table }}$ value (2.70) and sig. $(0.226)>$ probability value $(0.05)$.

Currently Indonesia is being hit by the COVID-19 Pandemic, so the condition of manufacturing companies in Indonesia is also having a big impact. Many companies went bankrupt and the economy declined drastically. However, manufacturing companies in Indonesia that are listed on the IDX tend to stay afloat because manufacturing companies in Indonesia are companies that provide the needs of the community, so they tend to survive today. It's just that, the turnover which is usually large has now decreased, which is a natural thing because the entire world is affected by COVID-19.

\section{CONCLUSIONS}

This research conclude that capital structure has no effect on firm value, namely by showing a significance value of more than $\alpha=0.05(0.382>0.05)$, meaning that the small amount of debt held by manufacturing companies from 2015-2019 in this study is not a reference for investors to glance at these companies, because for investors the most important thing is the company's performance, which is reflected in the company's profits. Moreover, the Investment Opportunity Set has no effect on firm value with the statistical significance value of more than $\alpha=0.05$ $(0.969>0.05)$, because investors prefer other factors that are easier to observe to value the company.

Next, profitability has an effect on firm value with a significance value less than $\alpha=0.05 \quad(0.045<0.05)$, meaning that manufacturing companies in 2015-2019 in this study tend to be able to generate profits with equity owned so that this can increase firm value. Lastly, capital structure, Investment Opportunity Set (IOS) and profitability simultaneously have no effect on firm value because Fcount (1.476) <Ftable value (2.70) and sig. $(0.226)>$ probability value $(0.05)$.

\section{REFERENCES}

[1] N. T. Bhutta and A. Hasan, "Impact of Firm Specific Factors on Profitability of Firms in Food Sector," Sci. Res. Open J. Account., 2013.

[2] U. Mardianti, G. N. Ahmad, and R. Putri, "Pengaruh Kebijakan Dividen, Kebijakan Hutang Dan Profitabilitas Terhadap Nilai Perusahaan Manufaktur," Equity, vol. 18, no. 2, p. 181, 2019.

[3] R. El Junusi, "Digital Marketing During the Pandemic Period ; A Study of Islamic Perspective," J. Digit. Mark. Halal Ind., vol. 2, no. 1, pp. 15-28, 2020.
[4] M. Sodikin, "Competitive Advantages of Sharia Banks: Role of Ihsan Behavior and Digital Marketing in New Normal," J. Digit. Mark. Halal Ind., vol. 2, no. 1, pp. 1-14, 2020.

[5] E. F. Brigham and J. F. Houston, Dasar-dasar Manajemen Keuangan Terjemahan. Edisi 10. Jakarta: Salemba Empat, 2011.

[6] A. Kohar and Akramunnas, "Pengaruh Struktur Modal dan Kebijakan Dividen Terhadap Nilai Perusahaan.," ASSETS, vol. 7, pp. 1-16, 2017.

[7] A. E. Prasetyo and I. Januarti, "Analisis FaktorFaktor Yang Mempengaruhi Struktur Modal Pada Perusahaan Manufaktur Yang Terdaftar Di Bursa Efek Indonesia Periode 2011-2014," DIPONEGORO J. Account., vol. 4, no. 4, pp. 1-8, 2015.

[8] K. H. Chung and C. Charoenwong, "Investment Options, Assets In Place, and The Risk Of Stocks," Financ. Manag., vol. 20, no. 3, 2013.

[9] D. Ayuningtyas, "Pengaruh Profitabilitas Terhadap Nilai Perusahaan: Kebijakan Dividen dan Kesempatan Investasi Sebagai Variabel Antara," Jurnal. STIESIA, vol. 13, 2013.

[10] R. Djalante et al., "Review and analysis of current responses to COVID-19 in Indonesia: Period of January to March 2020.," Prog. Disaster Sci., vol. 6, 2020 .

[11] Sugiyono, Metode Penelitian Kombinasi (Mix Methods). Bandung: Alfabeta, 2015.

[12] I. M. Sudana, Manajemen Keuangan Perusahaan Teori dan Praktik. Jakarta: Erlangga, 2011.

[13] Kasmir, Analisis Laporan Keuangan. Jakarta: PT Raja Grafindo Persada, 2015. 